\title{
The UK: Financial Globalization and Formalization of Banking Supervision
}

\subsection{A Brief History \\ of Commercial Banking in the UK}

The Bank of England was formed as the first joint-stock bank in history in 1694, and came to dominate commercial banking in the British capital for the following one and a half century. Until the mid-nineteenth century, it was the sole bank operating in the London region, while in other parts of the country small private bankers provided banking services to the merchants, the elites, and the businessmen of the industrializing economy. While the Bank of England was a privately owned, for profit commercial bank, its existence was and remained linked to its services as lender to the British government (Tilly 1989).

The private banks, funded by note issuing, mainly offered services of short-term loans to local merchants and businessmen, money exchanges, and settling payments. Very few operated more than one office. From the 1820 s and 1830s, merchant bankers developed as financiers and proprietary traders in an international commercial trade system with Great Britain as its center. The funding provided by banks was generally in relation to commercial trade. Several leading bankers, such as the Rothschild, acted as brokers to arrange large loans to governments and participated in market funding on the London Stock Exchange.

After a banking crisis in 1825, the Bank of England's monopoly on joint-stock banking ended partially with the enactment of the Banking Co-partnership Act of 1826. Joint-stock banks could now be

(C) The Author(s) 2022

E. Hotori et al., Formalization of Banking Supervision, https://doi.org/10.1007/978-981-16-6783-1_9 
formed outside the London region. However, few joint-stock banks were founded. The established private bankers actively opposed new competitors outside London, while the Act protected the Bank of England's banking monopoly in the capital. Since the new Act kept the joint-stock bank owners' personal liability, the benefits of the new company form remained limited (Grossman 2010).

In 1833 the Bank Charter Act ended the Bank of England's London monopoly, and the number of commercial banks grew very rapidly, from 48 in total in England in 1834 to 111 just two years later. The Act also allowed national branch networks, although only a few banks would develop until the last decades of the century (Barnes and Newton 2018). The new joint-stock banks, still without limited liability, were not allowed to issue notes for funding, and thus became dependent on the equity capital of the founders and on deposits (Tilly 1989).

The sharp growth in banks was followed by banking crises in the late 1830s and early 1840s. The crises set about a long trend of mergers and acquisitions that would pause first in the early 1920s. The mergers led to a gradual decline in the number of private banks and a growth in jointstock banks. From nearly 800 private banks operating in England (and Wales) in 1813 , the number decreased to just over 400 by 1850 and less than 200 by 1900 . In contrast, the number of joint-stock banks increased from zero in 1813 (except for the Bank of England) to 100 by 1900 (Davies et al. 2010). Via the mergers several commercial banks came to operate networks of branches around the country. Scale became an important element for the commercial banks that adopted the strategy of keeping up with the growing companies of industry and trade. By the end of the First World War, British banking was dominated by the "Big Five," namely Barclays, Lloyds, Midland, National Provincial, and Westminster Bank (Capie and Rodrik-Bali 1982).

The market continued to concentrate in the early twentieth century. Out of concern for the banking market being too concentrated, the banks accepted to base all further mergers on the approval of the UK Treasury in 1918. Although this arrangement was not regulated in law, the number of mergers fell significantly after this year (Wadsworth 1954: 780).

In the interwar years, the British banking sector, just as much of the industry, recovered more slowly than in many other countries. The US dollar overtook the UK pound as anchor currency in international trade and in the re-emerged gold standard. The British commercial banks focused on trade finance since investment capital was generated via the 
stock exchange. The UK financial system became market oriented, as in the US, while the German financial system, among others such as the Japanese and the Swedish ditto, became more bank oriented (Ross 1996).

In contrast to many other industrial economies, the UK did not experience any severe financial crisis during the first decades of the twentieth century. While the periods 1907-1908, 1920-1922, and 1929-1933 were turbulent for British banks, no banks were closed or offered liquidity. No banks called for other government rescue intervention in any of the crises (Davies et al. 2010). Most banks operated with high levels of liquidity for such periods, over $30 \%$ of total assets on average. At the sector level, the British banks managed the periodic slumps and recessions by more mergers and consecutive market concentration. By the middle of the twentieth century, the "Big Five" commercial banks had approximately $75 \%$ of total bank assets (Davies et al. 2010).

After the Second World War, the British economy recovered better, as did its banks. The banking sector was marked more by cooperation and coordination among the banks rather than competition. The currency controls and other quantitative controls implemented to uphold the Bretton Woods exchange rate regime contributed to this development, as did the cartel-like cooperation of the Big Five clearing banks. During the 1950s and 1960s, the British governments and the Bank of England accepted the limited competition in favor of market stability (Capie and Billings 2004).

The lack of competition nevertheless became a growing concern, and in 1971 the Competition and Credit Control Act was enacted to allow greater freedom of competition in the banking system. The credit controls, in force since the war, were removed and reserve ratios lowered, and the banks were allowed to compete with interest rates by new types of deposits (Schenk 2014). Average liquidity ratios went from around 25\% (cash to total assets) in 1965 to under 5\% in 1975 (Davies et al. 2010). The reforms led to a boom in lending and in the house market, in which many fringe banks and other credit institutions participated aggressively. In 1973 a number of these lenders on the fringes of the banking market came close to default in what became known as the "fringe" or "secondary" banking crisis. When the first oil-price shock ended the book abruptly in 1973, the clients and the banks got in deep trouble and were rescued by interventions by the Bank of England with some participation of the tier one, major banks (Schenk 2014). The crisis did not terminate the two-tier system, but weakened the fringe banks to the benefit of the 
major clearing banks. As the banking market became increasingly international in nature, the cartel-like arrangements between the "Big Five" gradually disappeared.

Since the late 1950s, more and more international banks and financial companies established offices in the British capital. The trades of the eurodollar markets, although largely existing outside or in between national jurisdictions, were largely carried on out of London. The British authorities, including the Bank of England, were supportive of the City reviving as a leading financial center of the world again, and they maintained very limited regulation and non-existing supervision of banks to attract financial businesses. By the 1980s, London was second only to New York in the US in volume, but leading in several markets (e.g. the Eurodollar market business for example). The City was also the most international center, with more than two thirds of all banks (nearly 600) operating in the UK being foreign owned or controlled (Cooke 1986). The number of foreign banks established in London increased from 53 in 1950 to 351 in 1980 (Baker and Collins 2005).

The reforms from the late 1970s and 1980s enabled the British commercial banks to compete on international markets. In something of a paradox, during the same time-period, bank-specific regulation and supervision were-finally-formalized.

\subsection{The Long RoAd TO Formal Banking Regulation}

As is well-known, the Banking Act 1979 was a milestone in the formalization process of banking supervision in the UK. The Bank of England first (reluctantly though) accepted the formal responsibilities for prudential supervision-this was a historic moment in the British tradition of informal bank regulation and supervision since the nineteenth century.

The first joint-stock bank in the UK was the Bank of England, established in 1659 mainly for fiscal budget purposes. It was privately owned and was granted a monopoly on joint-stock banking until 1826, when a legal reform allowed new joint-stock banks to form outside the London region. However, the reform-a consequence of the banking crisis in 1825-led to establishment of very few new banks. The private bankers around the country actively opposed new competitors. Since the new act kept the joint-stock bank owners' personal liability, the benefits of the new company form remained limited (Grossman 2010). 
A new reform came in 1833 when the Bank Charter Act ended the Bank of England's London monopoly. The number of commercial banks grew instantly, from 48 in England in 1834 to 111 in 1836. Following the crisis of 1836-1837, Sir Robert Peel's deep concern for domestic inflation led to new legal reforms in 1844.

The 1844 "Peel's Act," reformed the Bank of England by organizing it into two departments, separating the note issuing from the commercial banking. The act also gave the bank a monopoly on note issuing that was implemented gradually over the coming decades. The reform affected the private banks the most since many funded themselves with note issuing, and over the nineteenth century the private banks would fight a losing battle for business with the joint-stock banks. The second reform of 1844 brought them temporary respite however (Davies et al. 2010).

The Joint Stock Bank Act of 1844 formulated bank-specific regulations for the first time (Turner 2014). Up until then joint-stock banks had been regulated by general corporate law which favored free enterprise and very limited government intervention. Notably, the 1844 Act introduced a charter requirement for new banks (granted by the Privy Council). The owners and the statutes of the bank needed approval, and the owners also had to put up a minimum of $£ 100,000$ in equity capital, of which half had to be paid in before opening for business. Once in operation, the jointstock banks were required to publish monthly balance sheet (Grossman 2010).

The act's requirements reduced the incentives of starting a joint-stock bank. In 1857 it underwent major reforms: in practice all bank-specific requirements were removed. The British commercial banks once again were regulated by the general corporation law, which had been reformed in 1856. The benefits of the joint-stock form were boosted in the following year when limited liability was introduced (Grossman 2010).

Instead of formal regulation, the British banks were subject to informal institutions, such as the principles of business prudence shaped by experiences of crises such as in 1857 and 1878 . Unlike banks on the continent, the leading London banks refrained from adopting a universal banking business model, and these banks stuck to short term trade funding, brokering and cooperating in international loan consortia. An important feature of the prudence principles was to maintain high liquidity. By the late nineteenth century, the market concentration had also led to the creation of a socially homogenous elite in banking, which functioned as a social disciplining force against risky business. Also, a form of informal 
supervision was exercised by the Bank of England over the main clearing banks-a consequence of its occasional role as the Lender of Last Resort (Capie 2010).

The fact that the UK did not experience severe financial crises in the early twentieth century can possibly explain why the UK commercial banks remained largely exempted from regulation and supervision much longer than most other developed countries. ${ }^{1}$ Some regulatory reforms during the Second World War did however affect the banks and the structure of the banking sector.

Just as in many other countries, the British authorities introduced interest rate, credit and currency controls during the Second World War, and most of the regulations remained in force for many years after the war. The Exchange Control Act of 1948 authorized banks of good standing and size to act as clearing banks for the other banks (Reid 1986). This authorization, along with other policies in the 1950s and 1960s, established a two-tier banking system in the UK. The first or inner tier comprised of the large clearing banks, while the second tier comprised of smaller banks and other credit institutions. While the first tier was in regular contact with the authorities, the latter remained outside the view of the Bank of England and others. This made for uneven competition (Gardener 1986). For example, the requests by the Bank of England to reduce lending rates in the 1950s and 1960s were directed to the tier one banks specifically (Wadsworth 1954: 770). The second-tier banks and credit institutions emerged from the early 1960s—a very heterogeneous group in terms of business-operated mainly in wholesale banking with just certain retail services such as large term deposits and loans in foreign currencies (Gardener 1986).

With the consent of the Board of Trade (and its successor), commercial banks could be granted exemptions from complete account disclosures, something which was generally granted for proper "tier one" banks-as the Board determined (Reid 1986). The tier one banks had no tradition of published quarterly reviews that contained information about the bank of interest to its shareholders. Information about reserve funds were made public, although these were known to underestimate asset values

\footnotetext{
${ }^{1}$ One could draw the conclusion that the lack of regulation and supervision in fact was the reason why the UK banks did not experience banking crises. This would of course not explain why other countries without banking regulation and supervision, such as on the continent, did experience several crises before the reforms of the mid-1930s.
} 
and underreport inner reserves. Notably, information about both earnings and costs was not shared publicly (Wadsworth 1954).

With the reformed company act in 1967 a wider range of business organizations could offer deposit and credit services, as so called second tier banks. The Board of Trade determined which companies were banks, and whether they belonged to the tier one or two category. However, the Board did not conduct any follow-up supervisory activity of licensed companies, and also lacked all enforcement powers to discipline any misuse of the license privilege (Reid 1986).

As mentioned earlier, the 1971 Competition and Credit Control Act opened up for more competition among tier one and tier two banks, the latter operating with much less liquidity than their more prudent peers. Average liquidity ratios among banks rapidly fell from around 25\% (cash to total assets) in 1965 to under 5\% in 1975, and the reforms led to a boom in lending and in housing market where many fringe banks and other credit institutions participated aggressively (Davies et al. 2010).

In addition, the regulatory reforms reduced the entry barriers for foreign banks, which further intensified the competition (Gardener 1986). When the UK joined the European Economic Community in January 1973, some work had already been initiated regarding harmonization of banking regulation (Cooke 1986). And with the creation of the Basel Committee on Banking Supervision (BCBS) in 1974, more and more discussions on the banking regulation were held at the international level (Schenk 2014).

The secondary banking crisis in 1973-1975 was another triggering event for the formalization of banking regulation and supervision in the UK. The Bank of England was criticized for failing to spot the risks building up in the second-tier banks, although it had no formal mandate or powers to supervise the banks. The Bank of England had long opposed receiving banking supervision responsibilities, arguing that this would end the trust established between the central bank and the banking sector. However, with the enactment of the Banking Act in 1979 the British central bank was given statutory responsibility for supervising the deposit-taking institutions (Arch 2018).

The Banking Act introduced a license requirement for deposit taking institutions, ${ }^{2}$ and for the first time defined what a bank is in British law.

\footnotetext{
${ }^{2}$ The 1979 Banking Act also introduced a deposit insurance scheme for up to three quarters of their sterling deposits (up to $£ 7,500$ ). See Bingham (1992), for further details.
} 
In fact, two types of banks were defined reflecting the established twotier system. The second-tier banks, now called "licensed institutions," were required to send reports about its business and financial standing to the Bank of England on a quarterly basis. The act did not explicitly require the first tier, or "recognized banks" to do the same, but it was assumed that they would do so voluntarily just as before (Gardener 1986). The Banking Act 1979 gave the Bank of England the power to call licensed institutions to report all information for supervisory purposes. It could also appoint persons in order to conduct examinations of the licensed institution to investigate matters in relation to protection of depositors. Furthermore, the Act set certain conditions when the Bank of England could close the bank. However, the Act gave the Bank of England considerable discretion regarding its supervisory activities, and it used this discretion to maintain the arms-length and customs-based approach (Cooke 1982).

Following the failure of the tier-one bank, Johnson Matthey Bankers, in 1984 the political and public support for this approach came to an end. The failure of the bank-a subsidiary of Johnson Matthey \& Co established in 1965 to provide the company group's banking services and trade in bullion - forced the Bank of England to intervene to maintain the confidence in the gold market and the UK banking system (Bingham 1992). Not only had it failed to prevent the tier-one bank's failure, but its failure to convince other tier-one banks to participate in the rescue signaled an end of the "governor's eyebrow" approach over the City bankers and the unfulfilled adoption of a fully formal supervisory arrangement (Busch 2004).

To accommodate the critics, the Bank of England issued a white paper on "Banking Supervision" in December 1985, where it stated its aim to start meeting with the banks on a regular basis, on average twice a year. Such regular supervisory interviews aimed to take place at examined banks' own premises instead of the BoE's office. In the course of these meetings and in other contacts, the central bank would call for more detailed information from the banks than had been done before. ${ }^{3}$ The changes were not enough however, and in 1987 the Banking Act was reformed again. Notably, this reform ended the Bank of England's ability to conduct banking supervision informally.

\footnotetext{
${ }^{3}$ Bank of England, "Report and accounts for the year ended 28 February 1986", pp. $41-43$.
} 
The reformed Act required the Bank of England to report its supervisory activities on a regular basis to the Treasury, and the Bank had to publish the principles which would be used for authorizations and license criteria (Bingham 1992). To elevate supervisory issues more than before, a Board of Banking Supervision was created by the Treasury, comprising three representatives from the Bank of England as well as six "independent" expert members. The Bank was to report regularly to the new Board which was to provide expert advice on supervisory matters (Arch 2018).

The Act clarified that only licensed institutions were permitted to accept deposits, and specified the conditions when the Bank of England could revoke a license. The Act also ended some of the banks' granted exemptions from complete account disclosures, and required the bank's external auditors to report observed misgivings to the Bank of England. In addition, the Bank of England could impose restrictions or conditions upon any bank including the removal of a director or a manager, as well as limits on the grant of credit or the making of investments. Especially, large exposures to a single party or "closely related" parties were basically restricted below 10\% of the capital base (Collins et al. 2011).

While the rigid formal bank regulation and supervision were introduced with the Banking Act 1987, the trend of market liberalization continued in the 1980s. The securities markets liberalized in 1986 in a rapid series of reforms called the "big bang," which further strengthened the City's central role in international finance. In the same year the revised Building Society Act 1986 opened up for more direct competition for deposits and loans between commercial banks and the building societies. In 1988 the first Basel Accord was issued, with considerable input from the UK and the BCBS chairman Peter Cooke, which introduced internationally harmonized capital adequacy ratios as well as risk-weights for banks' assets (Goodhart 2011). While national exemptions remained concerning the regulation and supervision of commercial banks, it is fair to say that the process for reforms now was held at the international level.

\subsection{SUPERVISORY DEPARTMENT OF THE BANK OF ENGLAND}

The Banking Act 1979 for the first time gave the Bank of England statutory responsibilities and powers regarding supervision of deposit taking institutions. In the following year a Banking Supervision Division was 
created, headed by Peter Cooke. However, it maintained its arms-length and informal approach, and did not commit much for the purpose of banking supervision.

The internal organization of banking supervision grew out of the Bank of England's Discount Office. At the time of the fringe-bank crisis in the early 1970s, some banking supervisory activities were conducted by civil servants of the Office. A new department, the Banking and Money Market Section, took over these duties in 1974. The department was first headed by Peter Cooke, who also became the British representative to the BCBS (Bingham 1992). The number of staff working with supervision matters increased due to the crisis. The Discount Office had a staff ${ }^{4}$ of 15 in 1973, while the Banking and Money Market Supervision section had about 70 staff by 1978. By then the department was headed by George Blunden who would later replace Cooke as chairman of the Basel Committee on Banking Supervision (Reid 1986). However, given the lack of regulatory backing, the call-reports and other activities conducted by the Bank of England heavily relied on the voluntary cooperation of the banks. The newly created supervisory department remained to be limited in scope and purpose (Cooke 1986). The overall stance of the Bank was to maintain the relationship-based, arms-length approach.

In 1987, the Bank's organization for supervision underwent significant changes. As mentioned, the Board of Banking Supervision (BoBS) was created as a permanent, and formal, organization to monitor and council the Bank on supervisory matters.

\subsection{The Banking Supervision OF THE BANK OF ENGLAND}

In the UK, the banking supervisory activities evolved in the three steps: (a) prior to 1979 commercial banks followed informal supervisory practice, (b) from 1979 to 1986 formal banking supervisory system was introduced, but informal manner was preferred by the Bank of England, (c) after the Banking Act 1987 the banking supervisory practice was transformed into regular and standardized activity.

The informal banking supervision conducted by the Bank of England from the late nineteenth century until the gradual formalization in the

\footnotetext{
${ }^{4}$ It should be noted that those staff did not work exclusively with banking supervision.
} 
early 1980s was based on a number of informal institutions. As Cooke put it himself, the Bank of England's supervision "relied heavily on the fact that the City was a compact community exercising its own disciplines...which only required the Bank's intervention in extreme cases" (Cooke 1986). In addition, an important aspect was secrecy. Notably, the reputation of an examined bank was major concern for the supervisor (Capie 2010).

Before 1979, the Bank of England conducted its informal "governor's eyebrow" supervision over the clearing "tier-one" banks. The term "governor's eyebrow" reflected the relationship-based and confidential nature of the supervision. In practice it consisted of person-to-person meetings between the Bank of England Governors and the heads of the leading banks where the latter informed the former on their business operations, matters of concern and the latest market gossip in the City. The Governor could, if deemed necessary, raise an eyebrow of surprise and/or concern, and the bankers should take into consideration. As mentioned, this arrangement was based on the banks' willingness to accommodate the central bank's wishes and the mutual commitment to keep secret of this informal, "club-like" deliberations (Busch 2004).

The primary supervisory concern was bank liquidity, which averaged over $30 \%$ (of total assets) from the early twentieth century until the reforms to enhance competition in the 1960s and 1970s. However, given that the Bank of England only maintained regular contacts with the clearing and tier-one banks, the Bank could collect quite limited information about the expanding second tier of banks. The lack of mandatory license requirement for all deposit-taking institutions meant that the Bank did not even have a complete record of all banks operating in the UK.

As aforementioned, even after the fringe bank crisis and the 1979 Act, the Bank of England maintained its traditional informal supervision. In its communication with the banking community the Bank signaled that its supervisory approach would continue to "leave...room for debate, reasoned discussion and persuasion - of bankers by supervisors and vice versa" (Cooke 1986). While the Act empowered the Bank of England to conduct on- and off-site examinations of deposit-taking institutions, it gave the Bank room for discretion to continue to do these activities only sporadically and on informal terms (Norton 1991).

The banking supervisory activities became more systematic, regular, and standardized with the Banking Act 1987. From 1988, the Bank 
of England commenced to publish annual reports on banking supervision. ${ }^{5}$ Table 9.1 provides the summary of its supervisory activities from 1988 to 1995. The Bank of England administered applications for licenses and authorization for all deposit-taking institutions. Given London's importance in international finance, about half of the authorized financial institutions were incorporated outside the UK including branches of foreign institutions. The Bank of England operated as a hostcountry supervisor for these branches and had to develop international relationships with other banking supervisors for exchange of information in accordance with the BCBS Concordat of 1983. The prudential interviews were regularly conducted in the frequency of approximately twice a year. The powers of revocations and restrictions were also constantly exercised.

$$
* * *
$$

The UK case provides several interesting facts in comparative perspective. First, of course, it stands out as one of the last modern economies in the world to formalize banking supervision. It occurred about a century later than in the US. Differing experiences in the UK's financial history can explain this to some extent. In contrast to most countries in continental Europe, the UK did not experience a banking crisis in the late 1920sevents that triggered the formalization process in a half of our surveyed countries (i.e., Germany, Belgium, Switzerland, and France). When the UK did experience a banking crisis in the mid-1970s, regulatory reforms were made that started the formalization of banking supervision. The fact that the formalization process began comparatively late may also be related to the lack of strict bank charter requirements.

The reluctance of the Bank of England to adopt formal banking supervision duties slowed the formalization process however. Even after the Banking Act 1979 gave the central bank a formal supervisory objective, the Bank maintained the largely informal approach to monitoring the banks. Only with the banking crisis in 1984 as well as the international push for harmonized banking regulation did the banking supervision become fully formalized. Especially, the international forums for cooperation and sharing of information itself was the crucial factor to undermine the traditional mode of informal supervision in the UK and replace it,

\footnotetext{
${ }^{5}$ Bank of England, "Annual report under the Banking Act for $1987 / 88$ ".
} 
9 THE UK: FINANCIAL GLOBALIZATION ...

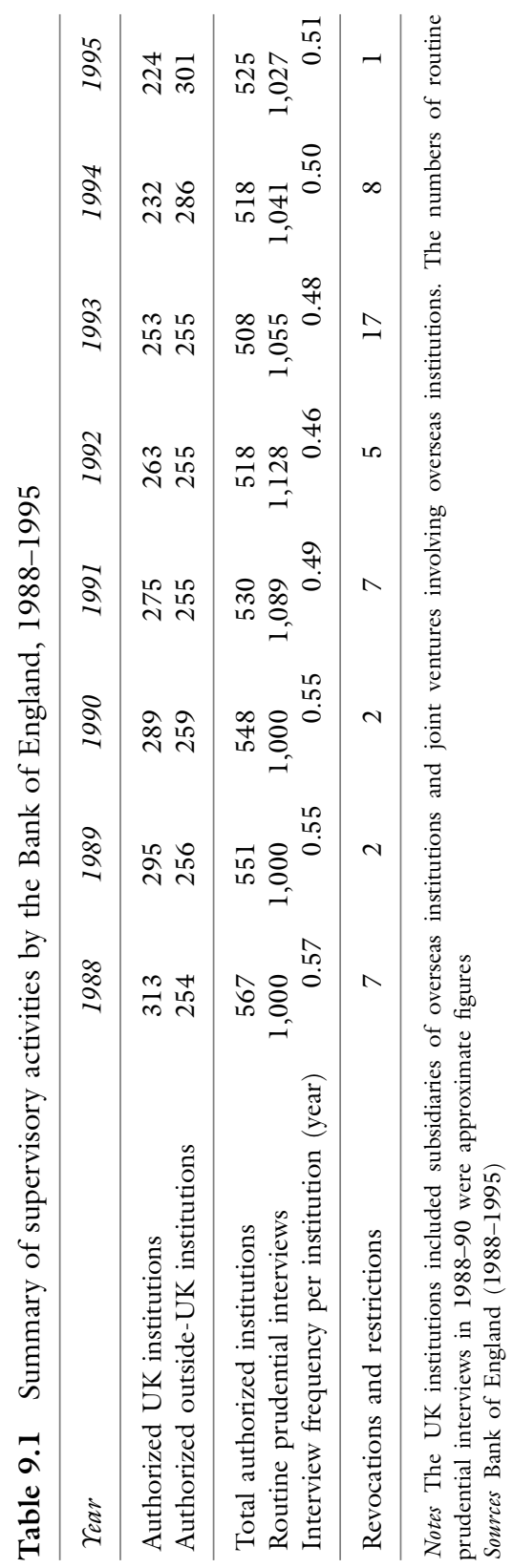


overlap it, with formal banking supervision. Thus, the UK case suggests that the financial globalization appeared as a final driver to formalize banking supervision.

\section{REFERENCES}

Arch, L. 2018. The Regulation of the London Clearing Banks, 1946-1971: Stability and Compliance. London: Palgrave Macmillan.

Baker, M., and M. Collins. 2005. London as an international banking centre, 1950-1980. In London and Paris as international financial centres in the twentieth century, ed. Y. Cassis and E. Bussière, 247-264. Oxford: Oxford University Press.

Bank of England. 1988-1995. Annual report under the Banking Act. London: Bank of England.

Barnes, V., and L. Newton. 2018. How far does the apple fall from the tree? The size of English branch networks in the nineteenth century. Business History 60 (4): 447-473.

Bingham, T.H., ed. 1992. Inquiry into the supervision of The Bank of Credit and Commerce International. Report to the House of Commons dated 22 October 1992.

Busch, A. 2004. National filters: Europeanisation, institutions, and discourse in the case of banking regulation. West European Politics 27: 1-28.

Capie, F. 2010. The Bank of England, 1950s to 1979. Cambridge: Cambridge University Press.

Capie, F., and M. Billings. 2004. Evidence on competition in English commercial banking, 1920-1970. Financial History Review 11 (1): 69-101.

Capie, F., and G. Rodrik-Bali. 1982. Concentration in British banking 18701920. Business History 24 (3): 280-292.

Collins, D., I. Dewing, and P. Russell. 2011. New roles for auditors and reporting accountants in UK banking supervision under the Banking Act 1987. Accounting, Auditing \& Accountability Journal 25 (3): 535-565.

Cooke, P. 1982. The role of the banking supervisor. Bank of England Quarterly Bulletin, December 1982: 547-552.

- 1986. Self-regulation and statute-The evolution of banking supervision. In UK banking supervision: evolution, practice and issues, ed. E. Gardener, 85-98. London: Allen \& Unwin.

Davies, R., P. Richardson, V. Katinaite, and Manning, M. 2010. Evolution of the UK banking system. Bank of England Quarterly Bulletin Q4: 321-332.

Gardener, E., ed. 1986. UK banking supervision: Evolution, pratice and issues. London: Allen \& Unwin.

Goodhart, C.A.E. 2011. The Basel Committee on Banking Supervision: A history of the early years 1974-1997. Cambridge: Cambridge University Press. 
Grossman, R.S. 2010. Unsettled account: The evolution of banking in the industrialized world since 1800. Princeton: Princeton University Press.

Norton, J. 1991. The Bank of England's lament: The struggle to maintain the traditional supervisory practices of 'moral suasion.' In Bank regulation and supervision in the 1990s, ed. J. Norton, 7-30. London: Lloyd's of London Press.

Reid, M. 1986. Lessons for bank supervision from the secondary-banking crises. In (1986) UK banking supervision: Evolution, practice and issues, ed. E. Gardener, 99-108. London: Allen \& Unwin.

Ross, D.M. 1996. Commercial banking in a market-oriented financial system: Britain between the wars. Economic History Review 49 (2): 314-335.

Schenk, C. 2014. Summer in the City: Banking failures of 1974 and the development of international banking supervision. The English Historical Review 540: 1129-1156.

Tilly, R. 1989. Banking institutions in historical and comparative perspective: Germany, Great Britain and the United States in the nineteenth and early twentieth century. Journal of Institutional and Theoretical Economics 145: 189-209.

Turner, J.D. 2014. Banking in crisis: The rise and fall of British banking stability, 1800 to the present. Cambridge: Cambridge University Press.

Wadsworth, J.E. 1954. United Kingdom of Great Britain and Northern Ireland. In Banking systems, ed. B.H. Beckhart, 769-837. New York: Columbia University Press.

Open Access This chapter is licensed under the terms of the Creative Commons Attribution 4.0 International License (http://creativecommons.org/licenses/ by $/ 4.0 /$ ), which permits use, sharing, adaptation, distribution and reproduction in any medium or format, as long as you give appropriate credit to the original author(s) and the source, provide a link to the Creative Commons license and indicate if changes were made.

The images or other third party material in this chapter are included in the chapter's Creative Commons license, unless indicated otherwise in a credit line to the material. If material is not included in the chapter's Creative Commons license and your intended use is not permitted by statutory regulation or exceeds the permitted use, you will need to obtain permission directly from the copyright holder.

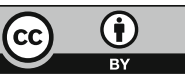

